\title{
How Are Student's Perceptions of Online Learning Evaluation During the Covid - 19 Pandemic?
}

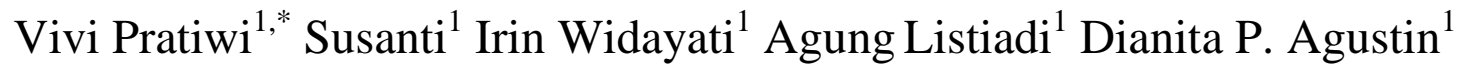 \\ ${ }^{1}$ Universitas Negeri Surabaya \\ *Corresponding author.Email: vivipratiwi@unesa.ac.id
}

\begin{abstract}
This study aims to determine student perceptions of online lecture evaluations, such as convenience to obstacles faced by students. This type of research is descriptive quantitative research, taking a purposive sample, namely students of Accounting Education, Universitas Negeri Surabaya. The data collection technique is a questionnaire. This study showed that students gave a positive response in the medium category of $57.3 \%$. Furthermore, it was found that all samples had heard of online evaluation by 103 students (100\%). The online evaluation implementation has proven to be very good for all accounting education study programs by 88 students (85.4\%). There were 94 students (91,3\%) have participated in the online evaluation. Students feel comfortable taking online rather than conventional evaluations as many as 84 students $(81.6 \%)$. Do not find it difficult to do the questions as many as 76 students (73.8\%). Learning applications used include Google Classroom, Gmail, Quizizz, which are easy to operate by 102 students (99\%). Students feel more comfortable in conventional than online evaluations as many as 41 people (39.8. Fluency in answering questions through online evaluation is 70 students (68\%). Online evaluation should be done only occasionally is 55 students (53.4\%). There was an increase in the subject's score as many as 81 students (78.6\%). The objectivity of online evaluation is 69 students (67\%). The relevance of the questions was 82 students (79.6\%). This research is expected to be used to find out the positive or negative perceptions and make different decisions.
\end{abstract}

Keywords: Perceptions, Online learning, Evaluation, Covid-19.

\section{INTRODUCTION}

The spread of Corona Virus Disease or Covid-19 in Indonesia is a strong reason for the government to implement a policy of limiting activities, one of which is in education. Based on the Circular of the Minister of Education and Culture Number 2 of 2020, students, students, teachers and other education personnel must postpone face-to-face learning activities and replace them with online learning [1]. Based on this decision, all educational institutions and others implemented online learning and worked from home. Online learning will certainly use supporting media that make it easier for students and lecturers to communicate, deliver material and evaluate learning.

Media and this access are very dependent on the development of technology in Indonesia. The survey results from the Indonesian Internet Service Providers Association (APJII) showed an increase in Indonesian internet users from 2017 to 2018 by 27.9 million users, bringing the total internet users in 2018 to 171.1 million users [2]. The amount of internet access and users in Indonesia will make it easier for students and lecturers to implement online learning. They are supported by learning applications such as Google Classroom, Email, WhatsApp, to Video Conference online. The urgency of implementing online learning to stop the spread of Covid-19 was also chosen because of the demands of the era of disruption where all activities use a technology system or online so that the learning process to evaluation of learning carried out online is expected to be able to improve students' digital literacy and skills in using technology.

In learning, evaluation is a critical process to determine the value and quality of the learning process, including assessing the achievement of learning objectives as a reference for decision-makers [3], [4]. When learning is done online, the learning process will change completely using technology with various conveniences and limitations. So, an online evaluation will use online media that also involves students accessing whether it makes it easier or vice versa. 
Based on the above conditions, Universitas Negeri Surabaya, Accounting Education study program implements an online learning evaluation system which in its implementation must pay attention to various user characters [5]. Evaluation of online learning must meet the requirements including; (a) the implementation of online learning, (b) positive mindset of lecturers and students about the impact of the internet and technology, (c) learning designs that can be learned by students, (d) evaluation of the entire learning process, (e) feedback from parties implementation [6]. Moreover, the development of technology also requires students to have expertise in using online evaluation tools. Therefore, knowing student perceptions is very important to help describe the effectiveness of the online learning evaluation system at the Higher Education level, especially at the Accounting Education Study Program, Universitas Negeri Surabaya.

Online evaluations are carried out when online learning demands occur due to efforts to prevent the Covid-19 virus. For this reason, this study aims to describe students' perceptions of online evaluation. Student perceptions of online evaluation include the suitability of the questions given in online evaluations with learning materials, ease of use of online evaluation media, to the level of objectivity in the application of online evaluations. Thus, student perceptions will describe the implementation to the benefits felt by students to be used as a reference for making decisions related to online learning and its evaluation system.

\section{RESEARCH METHODS}

This type of research is a quantitative descriptive study. The population of this study were all active students of the Universitas Negeri Surabaya (UNESA) Accounting Education study program, as many as 291 students. The sample used was 103 students who were determined by using a simple purposive sampling technique. The sample criteria used are active students of the Accounting Education study program who have taken lectures in the even semester of 2020/2021, assuming students have participated in online learning evaluations. The sample is considered relevant to the research objectives. Data was collected by distributing questionnaires to a sample of students to produce primary data from research subjects. The data obtained from the survey results are quantitative, so that they are analyzed descriptively quantitatively with the percentage technique. Quantitative data were obtained using the Guttman scale with yes or no intervals. Then the data obtained from the survey results were analyzed using the percentage technique. Based on various theories and previous research, the following is a questionnaire grid used as a research instrument to determine student perceptions of the implementation of online evaluations [7]:

Table 1. Research instrument questionnaire grid

\begin{tabular}{|c|l|}
\hline No & \multicolumn{1}{|c|}{ Questions } \\
\hline 1 & I have heard of online lectures \\
\hline 2 & I feel confident that online evaluations are very good for all courses in the Accounting education study program \\
\hline 3 & I have participated in online evaluations \\
\hline 4 & I feel more comfortable taking online evaluations than conventional evaluations \\
\hline 5 & I have difficulty answering the questions given during the online evaluation \\
\hline 6 & I can use applications that support online evaluation (such as google classroom, email, quizizz) \\
\hline 7 & I am more comfortable taking conventional evaluations than online evaluations \\
\hline 8 & I feel confident online evaluation can show the success of course learning \\
\hline 9 & I answer fluently during online evaluation \\
\hline 10 & I feel that with the online evaluation, my course grades have decreased \\
\hline 11 & I feel that online evaluation will be good if it is only done occasionally \\
\hline 12 & I feel that with the online evaluation, my course scores have increased \\
\hline 13 & I feel that online evaluations are not objectively placed on courses in the accounting education study program \\
\hline 14 & I feel that the questions given by the lecturer during the online evaluation are more in line with the learning \\
\hline
\end{tabular}




\section{RESULTS AND DISCUSSION}

Based on the research results conducted on students of the Accounting Education study program at the Universitas Negeri Surabaya, information was obtained about students' perceptions of the implementation of online evaluations during the Covid-19 pandemic. Students' perceptions of online evaluations can be explained in the following figure:

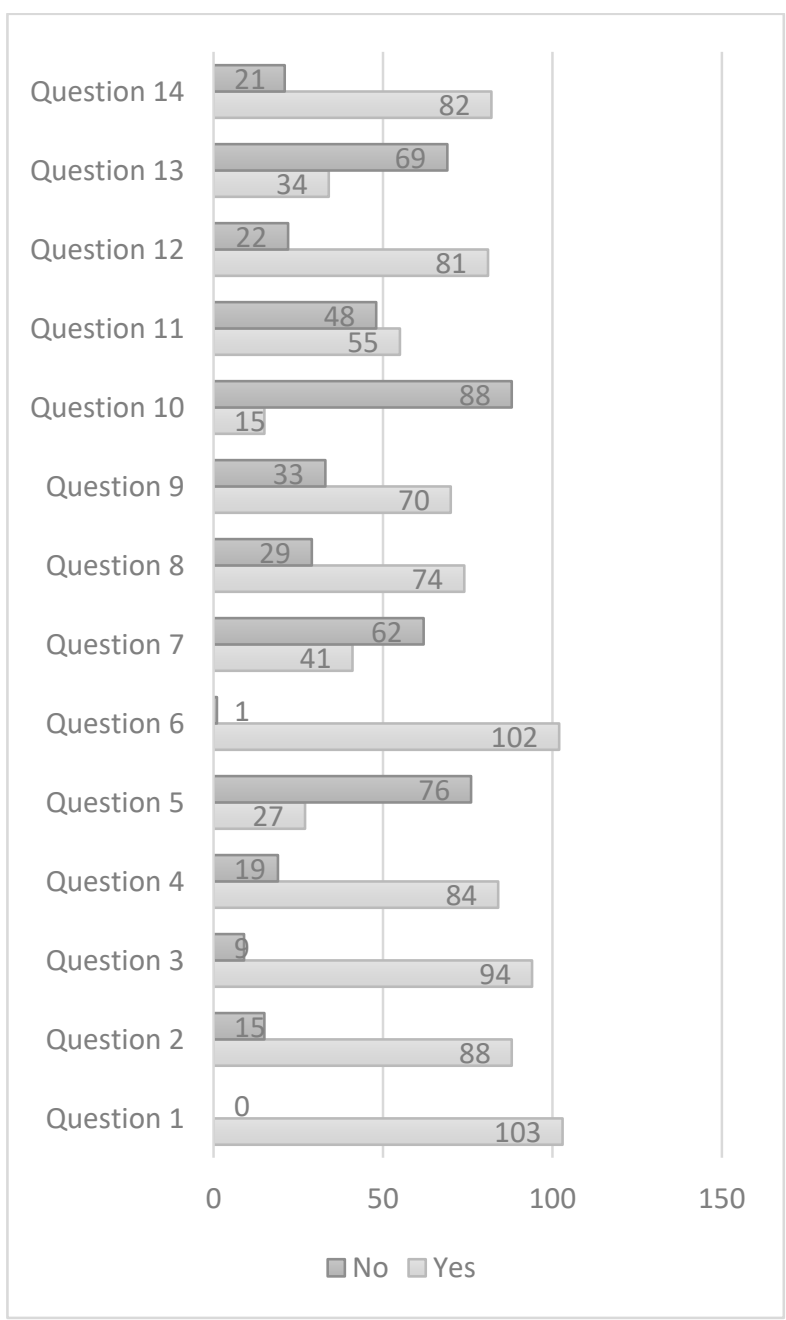

Figure 1 Students' perceptions of online evaluations

Based on Figure 1 above, it can be seen that all students of the Accounting Education study program have heard of online lectures. Furthermore, 88 (85.4\%) students of the Accounting Education study program feel confident that online evaluations are very good for courses in Accounting Education. In comparison, 15 (14.6\%) are not sure that an online evaluation for courses in Accounting Education is not good. This means that most Accounting Education students agree that online evaluation is excellent, carried out by various online evaluation methods considered more effective and more accessible. Based on previous research, some students did not agree that using the internet as a learning medium can make it easier for students to communicate and interact with lecturers because it can cause misunderstandings [8]. On the other hand, students feel that using various online media for learning is also beneficial for making the learning process easier, delivering material, collecting assignments for assessment [9].

Then, 94 (91.3\%) Accounting Education students have participated in the online evaluation. This is also related to the increasing spread of the Covid-19 virus, which requires the lecture process to be carried out online so that evaluations are also conducted online. Therefore, appropriate assessment models used in learning during the Covid-19 pandemic include online evaluation, portfolio assessment, and self-assessment [10]. After most Accounting Education students had taken online evaluations, the perception of convenience during online evaluations showed that $84(81.6 \%)$ students were more comfortable with online evaluations than conventional evaluations. The convenience of using online evaluations is related to the ease of internet access, and the platform evaluation used to find out the results of an evaluation. Although in previous research, some students argued that face-to-face learning was more attractive to students than online [6] when compared to conventional evaluations, it certainly had advantages in terms of convenience, including; more flexible than time and place, does not require much equipment, and the most important thing is the ease of accessing the platform used. With a figure of 84 (81.6\%), most Accounting Education students agree with the various advantages in terms of convenience in carrying out online evaluations compared to conventional evaluations.

In addition to being related to convenience, the evaluation aims to determine student learning outcomes during the course. For this reason, in an evaluation, questions or items are presented that can be a benchmark for a student's ability. Perceptions of online evaluation also pay attention to the level of difficulty of the items given to students. As a result, 76 (73.8\%) Accounting Education students had no difficulty answering online evaluation items compared to conventional ones. Furthermore, the learning outcomes will be followed by a more complex evaluation process to obtain a statement regarding the success of the competencies that have been achieved to attitudes and skills.

The online evaluation is supported by a platform or application that facilitates the evaluation. Of the applications that can be used online, the following are applications that are preferred and comfortable for students to use in conducting online evaluations:

Students in online evaluations use many applications. A total of 102 (99\%) Accounting Education students can and efficiently operate all applications. The applications are Google Classroom, Gmail and Quizizz. The selection of online evaluation 
applications is related to the convenience of students in evaluation. In addition, students' ability to operate a learning application will also provide technological literacy skills, better mastery of technology. Especially for Accounting Education students who focus on education, they will provide future references for designing online learning and evaluation [11].

In addition to making it easier for students to carry out online evaluations, the habit of using applications can provide technological literacy knowledge for future education students to develop learning with technology integration in it [12]. In this regard, choosing the proper online evaluation application can provide convenience for students. Based on the study results, $62(60.2 \%)$ Accounting Education students disagreed that conventional evaluations were more convenient than online evaluations. This means that students can compare the implementation of online evaluations more comfortably than conventional ones. When students feel comfortable in online evaluation because it is easier and more flexible, it will encourage them to be more confident, and independent learning arises. Online evaluation makes students more focused on the questions or screens of the device than discussing or cheating with other students [13].

In addition, learning success can be seen from the results of both online and conventional evaluations. As a result, 74 (71.8\%) Accounting Education students feel confident that online evaluation can show the learning success of each subject. That is, the success of learning shows the achievement of learning objectives [14]. The achievement of learning objectives can be assessed from the achievement of student abilities in terms of attitudes, knowledge and skills. Based on these results, most Accounting Education students agree that online evaluation can show the success of learning from the aspects of attitudes, knowledge and skills that are facilitated by learning applications that facilitate the evaluation. In terms of competence, a total of $70(68 \%)$ students of Accounting Education showed that they had successfully answered the questions given online. This convenience can indicate easy access in answering questions and the level of competence possessed by students during learning. This means that most Accounting Education students find it easier to work on the items during the online evaluation. Also, a total of $88(85.4 \%)$ Accounting Education students did not experience a decline in grades in online evaluation courses. Regarding the results in the previous points, such as the convenience of the online evaluation, ease of access to applications, and ease of answering questions, it shows a positive relationship that $85.4 \%$ of students did not experience a decline in grades when an online evaluation was conducted.

Furthermore, 55 (53.4\%) Accounting Education students agree that online evaluation is better done occasionally. Despite giving positive responses to the previous point, students agree that online evaluations are carried out only under certain conditions. This is related to the widespread Covid-19 pandemic because, in the beginning, there was an online evaluation even when educational conditions were affected by the Covid-19 pandemic, so most students agreed that online evaluations were carried out only under certain conditions. In addition, several 81 (71.6\%) Accounting Education students also agreed to experience an increase in learning outcomes when an online evaluation was carried out so that a total of $69(67 \%)$ Accounting Education students did not agree that online evaluation was said to be not objective, especially for the Accounting Education study program. The existence of this online evaluation shows a positive response by increasing student learning outcomes because online evaluations are considered objective in their assessment. Moreover, 82 (79.62\%) Accounting Education students also agreed that the items given during the online evaluation were also following the previously set learning objectives. The majority of students agreed that online evaluation provided improved learning outcomes was more objective in implementation.

Based on that categorical test. It can be concluded that students' perceptions of online lecture evaluations show a positive response. Here are the results of the category test. In addition, the category of student perceptions is included in the medium category with a percentage of $57.3 \%$, and the high category is $42.7 \%$. This value indicates that the online evaluation has been carried out well. The online evaluation went well, supported by choosing the right platform and not burdening students, namely Google Classroom, Gmail and Quizizz, 102 people (99\%). The ease and convenience of using the platform were followed by an increase in learning outcomes by 81 people $(78.6 \%)$. Here are the categorical test of student's perceptions:

Table 2. Categorical student's perceptions

\begin{tabular}{|l|l|l|l|l|l|}
\hline \multicolumn{2}{|c|}{} & F & Per cent & Valid Percent & $\begin{array}{l}\text { Cumulative } \\
\text { Percent }\end{array}$ \\
\hline \multirow{3}{*}{ Valid } & High & 44 & 42,7 & 42,7 & 42,7 \\
\cline { 2 - 6 } & Medium & 59 & 57,3 & 57,3 & 100 \\
\cline { 2 - 6 } & Summary & 103 & 100 & 100 & \\
\hline
\end{tabular}


So, it can be concluded that the results of this positive perception are due to the selection of a learning platform, the convenience and ease of answering questions, learning outcomes and the relevance of the questions to the material, which has also been maximized. For this reason, student perceptions show a positive response and can be considered for reference and decisions on how to carry out online lecture evaluations in the future.

\section{CONCLUSION}

Based on the results and discussion above about students' perceptions of online or online learning evaluations, it can be concluded that students agree that online evaluations provide learning success which is indicated by an increase in learning outcomes. Moreover, it proved by positive perspective with $(57,3 \%)$ in the medium category. Online evaluation will be successfully supported by the selection of online evaluation applications following students' conditions and abilities to facilitate the implementation of evaluations to be more effective and flexible. In addition, students agree that online evaluation encourages students to be more confident and independent in learning. So, this research is expected to be used as a reference that, based on student perceptions, online evaluation provides convenience and is suitable for use if supported by an easy-to-use learning platform. Another purpose of this study is to classify groups of students who experience convenience and obstacles through perceptions about online evaluations that have been submitted. With that, the campus can reflect on further steps to continue conducting online or conventional evaluations with specific characteristics by considering student perceptions.

\section{ACKNOWLEDGMENTS}

The authors would like to deliver gratitude to the Lembaga Penelitian dan Pengabdian Masyarakat (LPPM) of Universitas Negeri Surabaya for supporting this work.

\section{REFERENCES}

[1] Kemdikbud, Surat Edaran Nomor 2 Tentang Pencegahan dan Penanganan Corona Virus Disease (Covid-19). 2020, pp. 1-4.

[2] Asosiasi Penyelenggara Jasa Internet Indonesia, "Laporan Survei Internet APJII 2019 - 2020," 2020. [Online]. Available: https://apjii.or.id/survei.

[3] A. P. Munthe, "Pentingnya Evaluasi Program Di Institusi Pendidikan: Sebuah Pengantar, Pengertian, Tujuan dan Manfaat," Sch. J. Pendidik. dan Kebud., vol. 5, no. 2, p. 1, 2015, doi: 10.24246/j.scholaria.2015.v5.i2.p1-14.

[4] T. Hidayat and A. Asyafah, "Konsep Dasar Evaluasi Dan Implikasinya Dalam Evaluasi Pembelajaran Pendidikan Agama Islam Di
Sekolah," Al-Tadzkiyyah J. Pendidik. Islam, vol. 10, no. 1, pp. 159-181, 2019, doi: 10.24042/atjpi.v10i1.3729.

[5] D. S. Prawiradilangga, Prinsip desain pembelajaran. Jakarta: Kencana, 2015.

[6] S. Ningsih, "Persepsi Mahasiswa Terhadap Pembelajaran Daring Pada Masa Pandemi Covid19," JINOTEP (Jurnal Inov. dan Teknol. Pembelajaran) Kaji. dan Ris. Dalam Teknol. Pembelajaran, vol. 7, no. 2, pp. 124-132, 2020, doi: 10.17977/um031v7i22020p124.

[7] Erin and A. Maharani, "Persepsi Mahasiswa Pendidikan M Atematika Terhadap," vol. 7, no. September, pp. 337-344, 2018.

[8] N. Adijaya, "Persepsi Mahasiswa dalam Pembelajaran Online* *Pengembangan teori dari penelitian berjudul 'persepsi mahasiswa terhadap materi ajar pada pembelajaran online' yang telah dipublikasi di Jurnal Eduscience Vol. 3/1," Wanastra J. Bhs. dan Sastra, vol. 10, no. 2, pp. 105-110, 2018, doi: 10.31294/w.v10i2.3931.

[9] S. Riadi, E. N. Normelani, M. Efendi, I. Safitri, and G. Firza Ismi Tsabita, "Persepsi Mahasiswa Prodi S1 Geografi FISIP ULM Terhadap Kuliah Online Di Masa Pandemi Covid-19," PADARINGAN (Jurnal Pendidik. Sosiol. Antropol., vol. 2, no. 2, p. 219, 2020, doi: 10.20527/padaringan.v2i2.2151.

[10] I. F. Ahmad, “Asesmen Alternatif Dalam Pembelajaran Jarak Jauh Pada Masa Darurat Penyebaran Coronavirus Disease (Covid-19) Di Indonesia," Pedagog. J. Pendidik., vol. 7, no. 1, pp. 195-222, 2020, doi: 10.33650/pjp.v7i1.1136.

[11] S. H. Nasution, "Pentingnya Literasi Teknologi bagi Mahasiswa Calon Guru Matematika," J. Kaji. Pembelajaran Mat., vol. 2, no. 1, pp. 14-18, 2018, [Online]. Available: http://journal2.um.ac.id/index.php/jkpm/article/vie w/3168.

[12] D. A. Kusumawardhani and B. Burhanuddin, "Analisis Kepuasan Peserta Didik Terhadap Layanan Evaluasi Hasil Belajar Online," J. Adm. dan Manaj. Pendidik., vol. 3, no. 1, pp. 90-101, 2020, doi: 10.17977/um027v3i12020p90.

[13] A. S. Syarifudin, "Impelementasi Pembelajaran Daring Untuk Meningkatkan Mutu Pendidikan Sebagai Dampak Diterapkannya Social Distancing," J. Pendidik. Bhs. dan Sastra Indones. Met., vol. 5, no. 1, pp. 31-34, 2020, doi: 10.21107/metalingua.v5i1.7072.

[14] N. Nuriyah, "Evaluasi pembelajaran: Sebuah Kajian Teori," J. Edueksos, vol. 3, no. 1, pp. 73 86, 2014, doi: 10.1165/rcmb.2013-0411OC. 